\title{
Taxonomy Construction and the Normative Turn in Religious Studies
}

\section{Travis Warren Cooper}

Departments of Anthropology and Religious Studies, Indiana University, Sycamore Hall 230, 1033 E. 3rd Street, Bloomington, IN 47405, USA; travcoop@indiana.edu

Received: 1 September 2017; Accepted: 6 December 2017; Published: 13 December 2017

\begin{abstract}
Jonathan Z. Smith contends that a taxonomic agenda underlies the study of religion. Before Smith, structuralist scholars saw it as their task to uncover the roots of human taxonomic arrangements that present themselves as natural. Drawing somewhat anachronistically on Smith's taxonomic model, I argue that underlying investigative categories posed by structural anthropologists are operative strategies of subjective value and valuation. I employ Smith to amend structuralist classificatory paradigms and to speak to questions of normativity, values, and concealed agendas in the contemporary study of religion. Smith's comparative program serves as a fertile territory of encounter between divergent religious studies subfields. In short, I argue that although the normative turn in religious studies has generally succeeded in deconstructing appeals to scholarly objectivity, it faces challenges along other parameters.
\end{abstract}

Keywords: the study of religion; categories; taxonomy; normativity and values; Jonathan Z. Smith; structuralism; social anthropology

Categorization is the mental operation by which the brain classifies objects and events. This operation is the basis for the construction of our knowledge of the world.

-Cohen and Lefebvre (2005, p. 2)

There is only a seeing from a perspective, a "knowing" from a perspective, and the more emotions we express over a thing, the more eyes, different eyes, we train on the same thing, the more complete will be our "idea" of that thing, our "objectivity."

-Nietzsche [1913] (2003, p. 86)

This article proceeds chronologically. In the first and second sections, I briefly summarize the program of the twentieth-century structuralist school and discuss the origins of taxonomic inquiry in the work of Emile Durkheim and Marcell Mauss. ${ }^{1}$ In the third section, I consider Claude Lévi-Strauss's contributions to the structuralist tradition's categorical methods, identifying the ways in which he builds upon Durkheim and Mauss. Then, in the fourth section, I explore criticisms of the structuralists posed by theorist and historian of religion Jonathan Z. Smith, and, in five, synthesize the implications of the respective scholars' methods and positions. In the sixth and seventh sections, I draw from Smith

1 Whereas functionalism typically refers to the work of Bronislaw Malinowski and Raymond Firth and studies individuals, social institutions, and sociocultural frameworks that influence individuals, structural-functionalism refers to A. R. Radcliffe-Brown and E. E. Evans-Pritchard's early work and investigates the role of individuals embedded in social orders, including the construction and maintenance of the social order. The structuralism I'm largely concerned with in this article derives from an entirely different school altogether: French structuralism. Still even more confusingly, after the 1960s some British scholars found the work of Claude Lévi-Strauss useful, applying the term British structuralism to their own scholarship. This new collective was not British structural-functionalism, as previously conceived, but the French variation of structuralism subsumed into British camps (Barnard 2000, p. 61 ff.; Porth et al. 2009). 
to comment on the recent embrace of normativity in religious studies. From a descriptivist position, I critically review Kevin Schilbrack's and Thomas Lewis' respective arguments, tracing through their work a genealogy of the taxonomic classification system. I explore taxonomy construction because of its usefulness for examining appeals to objectivity or normativity, stances that often appear to function in religious studies discourses as competitive impulses.

As a scholar trained in largely descriptivist methodologies, I aim to accomplish four things: (1) to suggest tentatively, using these and other key structuralist scholars as data for analysis, that stances of description vs. evaluation - one dichotomy proceeding out of a larger discussion about "objectivity" and "normativity" - are intimately connected to questions of agency, action, and power; (2) to argue that Smith offers a productive method by which scholars of religion might recognize their own inevitable situatedness and positionality, study the actions of others, and produce valuable secondary taxonomies; and (3) to contend that religious studies subdisciplines will find in Smith's taxonomic proposals some shared ground. ${ }^{2}$ The construction of explanatory categories and data sets, after all, is a necessary and useful tool of the academic trade. But as Smith suggests, taxonomy-making and the stipulating of data for study are neither value free nor objective operations. Sometimes taxonomic productions say as much about the predilections and biases of the scholar as they do their subjects of study. Smith offers a productive set of methods for discussion in light of the current impasse over normativity in religious studies. Finally, (4) I suggest that although the normativity proponents have successfully challenged conceptions of what counts as "critical" scholarship and deconstructed appeals to "objective" or "neutral" scholarship, some significant blind spots remain.

\section{Introducing Structuralism}

One postulate of classic or midcentury structuralism, especially notable in the 1960s and 1970s, is that social structure, either apparent or otherwise, has priority over agency. "Basic to the approach," Gordon Marshall notes, "is that we can discern underlying structures behind the often fluctuating and changing appearances of social reality." ${ }^{3}$ According to the structuralists, underlying structures or categories of the mind causally influence people as they organize the world around them. Scholars in the classic structuralist tradition excavated binaried oppositional structures they were certain evidenced the internalized social systems present within human persons. "Hidden (unconscious) laws or structures" resided just "beneath surface manifestations" (Marshall 1998, pp. 646-48). ${ }^{4}$

Structuralists made several other claims about the nature of the world. First, social and cultural particularities may vary according to social context and historical location. Relativistic stances notwithstanding, the structuralists argued that a sociocultural system's foundational elements remain primarily constant and enduring. In other words, structuralism partly resisted strong forms of cultural relativism and pushed for something of a unifying perspective of human mental organization. ${ }^{5}$ Second, formative structures determine for humans what appears as normal, routine, common sense, or natural.

2 I will distinguish in the following between critical religious studies scholars (i.e., those scholars who argue for the exclusion of theological approaches from the academic study of religion) and the normativists (i.e., those scholars who, among other endeavors, seek to afford for a more nuanced approach to defining "theology" and even allow that some forms of the subdiscipline should have a place in religious studies).

3 British social anthropologist Mary Douglas offers a quintessential definition of culture from a structuralist perspective: "a series of related structures which comprise social forms, values, cosmology, the whole of knowledge and through which all experience is mediated" (Douglas 1966, p. 128).

4 For instance, Douglas writes that "primitive culture must be taken to be unaware of itself, unconscious of its own conditions" (Douglas 1966, p. 91; for more on the unconscious and hidden aspects of culture, see Hall 1989). Although cognizant of the problems with the ethnocentric and imperialist origins of descriptive terminologies such as primitive, she offers an insightful take on the necessity of terms to differentiate societal types while also insisting on "the unity of human experience" (Douglas 1966, pp. 74-78 ff., esp. 77; c.f. Geertz 1973, p. 62).

5 To structuralist anthropologists, cultural and regional differences mattered, but not as much as the deeper structures they viewed as underwriting and connecting all human societies. 
Third, structuralism, in its strongest forms, depicted humans as products of an underlying system of formation rather than as creators of their own social realities (Marshall 1998, pp. 646-48). ${ }^{6}$

\section{Proto-Structuralist Classification Strategies: Durkheim and Mauss}

Although historians often identify anthropological accommodations and applications of linguistic structuralism as the foundation of the structuralist school, its origins predate Lévi-Strauss (Douglas 1966, p. viii). The roots of structuralist classification paradigms lie most evidently in the works of Durkheim and Mauss. In their shared project, Primitive Classification (Durkheim and Mauss [1903] 1963), Durkheim and Mauss delineate a mechanistic theory of human representations. According to their model, the unique purpose of sociology is to "retrace and explain" the foundational organizing structures and classification systems at the root of human social and cultural life (Durkheim and Mauss [1903] 1963, p. 3). ${ }^{7}$

Several themes from the work of Durkheim and Mauss carry over into midcentury structuralism. First, I examine the hidden or concealed nature of categorical origins or sources, a subject at the heart of the structuralist theoretical program (Briggs and Meyer 2009). For Durkheim, shared "categories of thought" serve as the "first instance" of "states of the collectivity" (Durkheim [1912] 2001, p. 117). In their sociocentric model, Durkheim and Mauss note that the "reasons which have led to the establishment of the [socially and culturally normative] categories have been forgotten, but the category persists and is applied, well or ill, to new ideas" (Durkheim and Mauss [1903] 1963, pp. 86-87, emphasis added). The human person finds himself or herself embedded within social systems not necessarily of his or her own choosing. The person experiences, embodies, and takes on social norms, traditions, and mores "already formed, and, as it were, instituted, because he [or she] is not their author, but receives them from outside-they are thus pre-established" (Mauss [1901] 2005, p. 10). Questions of freedom, constraint, and concealment will also carry over into the work of the normativists and their opponents who I examine at the end of this article.

Second, a brief comment on the role of valuation (i.e., an act of critical appraisal or the attribution of value, worth, or significance to an entity) on behalf of the fathers of sociology. For Durkheim and Mauss, constructions of taxonomic systems inevitably reveal a hierarchized understanding of the entities subsumed within the categorical system: "Every classification implies a hierarchical order for which neither the tangible world nor our mind gives us the model" (Durkheim and Mauss [1903] 1963, p. 8). "Indeed," writes Durkheim, "the function of categories is to dominate and encompass all other concepts" (Durkheim [1912] 2001, p. 335). Durkheim and Mauss are therefore attentive to valuating paradigms and power dynamics inherent in structured taxonomic genres. In totemic systems, for instance, "relations are thought of as relations between possessors and things possessed" (Durkheim and Mauss [1903] 1963, p. 24). All taxonomies are hierarchies. All hierarchies involve power.

Finally, an aside on the problematic descriptive/prescriptive divide. Durkheim and Mauss operate in a positivist era. Therefore, they focus on the taxonomic systems of the subjects whom they study. Durkheim and Mauss are at points dutifully concerned with what the study of the other reveals about "civilized" people. At points, they also do appear to move past objective description to the realm of prescriptive evaluation. However, the role of the scholar in the production and application of evaluative taxonomies remains largely unmentioned and thus unexamined. In studying first-order

6 For a critical take on structuralism's focus on system and pattern, see Geertz (1973, p. 351).

7 For more on the centrality of classification to the structuralist endeavor, see Durkheim and Mauss's concept of the classificatory function (Durkheim and Mauss [1903] 1963, p. 4). Classification systems have "a considerable prehistory" and scholars must inquire as to the developments that lead to the formation of particular taxonomic paradigms. Further, humans are deeply classificatory and taxonomy-constructing beings and the classification of things-including phenomena, events, behaviors, animals, and people-has serious ramifications for social arrangements (Durkheim and Mauss [1903] 1963, p. 11; c.f. Cosman [1912] 2001, p. xxv and Durkheim [1912] 2001, p. 112). No known society exists that does not classify things and people to some degree and for some social and functional purchase (Mauss [1901] 2005, p. 66). Durkheim argued that the abandonment of social categories may ultimately even lead to the breakdown of society (Durkheim [1912] 2001, pp. 18-19). 
(i.e., native) taxonomic systems, Durkheim and Mauss do not recognize the similarities to their own second-order (i.e., scholarly) classifications.

\section{The Emergence of Structuralist Reflexivity: Lévi-Strauss}

Enter Lévi-Strauss. His The Savage Mind (Lévi-Strauss 1973) is to some degree an extension of Durkheim and Mauss's project. Like his sociological predecessors, Lévi-Strauss foregrounds human perception of the world as he seeks to locate the roots of human classification systems. "Any classification is superior to chaos," he writes, "and even a classification at the level of sensible properties is a step toward rational ordering." Where his predecessors admit that so-called "primitives" engage in proto-scientific logic, Lévi-Strauss goes further, claiming that "Neolithic, or early historical, man was therefore the heir of a long scientific tradition" consistently engaged in a "science of the concrete" requiring that "everything must be taken account of" (Lévi-Strauss 1973, pp. 9, 15, 17; see also Lévi-Strauss 1961, p. 127).

Lévi-Strauss's discussion of the cultural bricoleur - an ideal type that draws, here and there, from bits and pieces to parcel together a semi-haphazard but meaningful whole-challenges some readings of the structuralist school as being entirely dismissive of human agency. In The Savage Mind, the reader observes an uneasy relationship between personal freedom and inhering systems of enablement and constraint. Modes of thought, action, logics, and behavior actually "consist of odds and ends left over from psychological and historical processes" (Lévi-Strauss 1973, p. 35; Lévi-Strauss 1961, p. 135). Constraint exists, but not in a completely deterministic fashion (Lévi-Strauss 1961, p. 160). The bricoleur draws on existing structural remnants but may repurpose or revise the codes for new modes of action and behavior. Myths "have had a use," for instance, but "they can be used again either for the same purpose or for a different one" (Lévi-Strauss 1973, p. 35, emphasis in the original). ${ }^{8}$ Lévi-Strauss appears to admit at least a limited degree of agency, anticipating Smith's preference of the homo faber descriptor over that of homo religiousus. ${ }^{9}$

Categorizations and taxonomies (i.e., emic or "native classifications") fill Lévi-Strauss's works. Complex formations of tribal, clan, and totemic systems ultimately result in "classification of classifications" (Lévi-Strauss 1973, p. 151; Lévi-Strauss 1963). Classification systems, certainly, are inherited and passed on (Lévi-Strauss 1973, p. 232). ${ }^{10}$ Both Durkheim and Mauss as well as Lévi-Strauss take interest in taxonomic structures whose origins and rationale have been lost over time. Anticipating contemporary philosophers of religion working in a normative vein, the human agent is in a dialectical sense both conditioned and free. Lévi-Strauss's bricoleur is not entirely free in his purposeful blendings since pre-existing patterns of system and structure ultimately determine the very choices at his disposal. The existence of the bricoleur also appears to complicate the hiddenness of structured sources as it gestures at the awareness and possible intentionality of the subject.

But what about valuation, positionality, and this descriptive/prescriptive divide? Like the proto-structuralists, Lévi-Strauss still views the scholar through positivist, even romanticized, lenses. Clifford Geertz criticizes Lévi-Strauss along these lines: for depicting the ethnographer as either (a) the disillusioned explorer of primitive tribes tarnished by modernity's influence and spread, or (b) the objective documenter and recorder of other ritually and culturally embedded social formations. Lévi-Strauss's consistent attention to taxonomy and structure does refer, for the most part, to his

8 Myth and ritual play important roles in structuralist paradigms. Lévi-Strauss's systematic and mechanistic structural language, in fact, is even more evident in his discussion of myth, which he sees as existing within and making use of structure (Lévi-Strauss 1973, p. 26). Ritual derives from "an asymmetry" between cultural and religious phenomena (ibid. p. 32). Myth and ritual proceed directly out of structure.

9 Douglas also leaves room for the creativity of cultural actors (see esp. Douglas 1966, pp. 5, 76-77 ff.). For an opposing view, see Hall (1989).

10 The structuralists argue that to be social is to classify. Classification is an inherently social function that encompasses totemism, kinship arrangements, rituals, and other practices. "Society is possible only if the individuals and things that compose it are distributed into different groups, that is, classes, and if these groups themselves are classified in relation to each other" (Durkheim [1912] 2001, p. 339). 
research subjects' embeddedness in cultural traditions. Although the ethnographer's paradigmatic task, in fact, is to trace the origins of existing structures, Lévi-Strauss still assumes the ethnographer to be an objective descriptivist.

Yet, in The Savage Mind, Lévi-Strauss complicates the analyst/analyzed binary in that he offers nothing short of a totalizing theory of the human mind, thereby implicating scholars themselves. ${ }^{11}$ He rejects dismissive and patronizing armchair philosophies of uncivilized peoples and argues that so-called primitive groups think logically, systematically, and scientifically. Myth, ritual, religion, and tradition-all those narrow social flourishes denigrated by critical Enlightenment minds-are simply appendages of logical minds that consistently and perpetually divide, classify, and categorize the world. In The Savage Mind's final chapter, "History and Dialectic," which contains his famous criticism of Sartre, Lévi-Strauss concludes that "the savage mind totalizes" (Lévi-Strauss 1973, p. 245). The savage mind-rationally qualifying, evaluating, and classifying-refuses "to allow anything human (or even living) to remain alien to it." Caught up in the problematic concept of "the savage mind" is the "scholarly," "Western," or "civilized" mind. But the assumed divide between "logical" and "prelogical mentality" is nothing more than a "false antimony" (ibid. p. 268). The savage mind is not savage; the savage mind is all of us. Either savage people don't exist or everyone- "Westerners" and intellectuals included-is savage.

Lévi-Strauss's taxonomy of taxonomies now makes sense. Sartre's infamous categories of primitive and civilized, through the aid of what Lévi-Strauss dismisses as "gratuitous contrasts" (Lévi-Strauss 1973, p. 249), serve as a mere distancing mechanisms postulated between the self and others. Lévi-Strauss begins to collapse any sort of divide between descriptive and prescriptive scholarly postures as he both documents the taxonomic practices of his informants and questions the distancing mechanisms implicit in existing scholarship. He thus paves the way for the meta-analytical theorist and historian of religion, Jonathan Z. Smith, to follow later. ${ }^{12}$

\section{Taxonomic Reflexivity in the Study of Religion}

From the outset, Smith criticizes several schools of inquiry, including functionalism and structuralism. His goal is to arrive at a method that involves "systematic description and comparison" (Smith 1982, p. 25). In his brief survey of methodologies he rejects functionalism's descriptions of culture as integrated and efficient (ibid. p. 18) and classifies the structuralist field as operating under "Marxist rather than Idealist presuppositions" (ibid. p. 25). Smith welcomes the Marxist shift but faults the structuralists and post-structuralists for failing to "come to clarity" regarding what he deems "the historical": "To the degree that [the structuralist field] is comparative, it falls prey to the strictures on morphology; to the degree that it has been interestingly historical (e.g., M. Foucault), the comparative has been largely eschewed." Smith thus envisions his work as pushing past structuralism's weaknesses by calling for a duly historical and robustly comparative program of study. Smith problematizes structuralism but also finds himself acting in an academic milieu enabled by its methodological

11 Even in Tristes Tropiques (Lévi-Strauss 1961), Lévi-Strauss waxes reflexive, speaking of the embeddedness of his own thought processes in "structural affinities" and as influenced by "deep-lying motives" (ibid. p. 56). Geertz, in a vein of meta-analytical criticism toward Lévi-Strauss, also applies structuralist paradigms to the structuralists themselves. Lévi-Strauss's books are, in Geertz's words, "variant expressions of the same deep underlying structure: the universal rationalism of the French Enlightenment" (Geertz 1973, p. 356). At the end of his epic Tristes Tropiques, and foreshadowing Smith's argument, Lévi-Strauss reflects on the role of the anthropologist in determining what is and is not worthy of study (Lévi-Strauss 1961, p. 383 ff.). While Douglas also writes about the self-application of anthropological theorizing (Douglas 1966, esp. p. 28), Geertz gestures toward the anthropologist's focus on self by way of the study of the other: "Bent over his own chips, stones, and common plants, the anthropologist broods, too, upon the true and insignificant, glimpsing in it, or so he thinks, fleetingly and insecurely, the disturbing, changeful image of himself" (Lévi-Strauss 1973, p. 54; on Lévi-Strauss's version of structuralism, see pp. 346-59).

12 For a review of Smith's biography and the origins of his concepts of taxonomy and comparison, see the essay "When the Chips are Down" in his Relating Religion: Essays in the Study of Religion (Smith 2004). See also Levene (Levene 2012, p. 1010). 
commitments. ${ }^{13}$ Although he challenges the structuralist paradigm, he actually "prefers structuralism to phenomenology, Lévi-Strauss to Frazer, Emile Durkheim and Marcel Mauss to Gerardus van der Leeuw" (Levene 2012, p. 1012). Phenomenological approaches to the study of religion, Smith argues, make the misguided attempt to locate and define the "essences" of the different religious traditions. For Smith, no religion can be taxonomically described with only a single, essential trait (Smith 1982, p. 7). Phenomenology may in fact ignore what Smith describes as central to the effectiveness of myth and ritual: the presence of incongruity (ibid. pp. 62-63, 90-101; Smith 1993, pp. 293, 299-310).

In several essays published in Imagining Religion, Smith turns the study of native classifications on its head. He also opens the horizon of inquiry by including the scholar in the process. Smith's reflexive turn-which I'm here discussing as an inward refocus on method, scholarly practice, and the construction and application of theory—owes something to its structuralist predecessors. "The advent of structuralism," Geertz tellingly writes of the field, "has done rather more to alter anthropology's sense of itself than its sense of its subject" (Geertz 1998, p. 25). Because "there is no data for religion" and because "religion" is a secondary scholarly construct "solely the creation of a scholar's study" (Smith 1982, p. xi), Smith suggests scholars make a decisive introspective turn. "Religion has no independent existence apart from the academy," Smith insists, overstating the situation and obscuring the mutually constitutive ways in which terms take on sociolinguistic meaning both inside and outside of the academy (ibid. p. xi; c.f. Smith 1998). ${ }^{14}$ Regardless, Smith is correct that religion as a taxonomic category of inquiry proceeds out of modernity. But because religion is conjured for use as a classificatory mechanism, "the student of religion, and most particularly the historian of religion, must be relentlessly self-conscious." Self-conscious reflexivity, in fact, constitutes the scholar's "primary expertise" and "foremost object of study" (Smith 1982, p. xi). Scholars of religion, on Smith's view, must operate as masters of intentional self-awareness and careful reflection (c.f. McCutcheon 2015, p. 3).

I've already briefly discussed the roots of self-reflection in Lévi-Strauss's work. Geertz also notes the role of structuralism in bringing about the reflexive turn. Smith adopts the structuralists' reflexive turn but highlights some of the school's deficiencies. Douglas (1966), he rejects functionalist views of culture as "well-articulated, highly integrated" mechanisms, opting instead for a messier view of social formation (Smith 1982, p. 18). Smith partly shares with the structuralist school his meta-analytical insistence and consistent focus on categorization and taxonomy in the study of religion. If Lévi-Strauss's The Savage Mind offers something of a classification of classifications, Smith extends this project to religious studies.

For Smith, "'classification' and 'taxonomy' are practices and pedagogies." Further, "classification and taxonomy do not simply name Smith's ... work. They stand for it" (Levene 2012, pp. 1010-11). Reminiscent of Foucault's description of modernity as having a "taxonomic impulse" (see Foucault 1994, pp. 51-57, 71-76, 125-132; Foucault 1972, pp. 178-95), Smith posits that the study of religion has a determined "taxonomic agenda." It's also important to keep in mind that for Smith, recalling Durkheim's note about exclusion and inclusion, "properly constructed" taxonomies share the "central feature" of hierarchy (Smith 1982, p. 2). In other words, and anticipating the work of the normativists to follow, taxonomies are neither value free nor objective. Taxonomies and pronouncements of what counts as data are embedded in relations of power and authority in academic social settings.

Scholars of religion, Smith continues, have engaged unproductively in a quest for the "unique and definitive sine qua non" or "that without which" "religion would not be religion but rather an instance of something else" (Smith 1982, p. 5). Attempts to locate and determine such an essence, according to

13 I might at this point note the ironies of social theorists themselves caught up in authoritative theoretical structures, filtering through and appropriating the academic myths at their disposal (c.f. Lincoln 1999, p. 209), or caught in their own partially self-spun webs of significance (c.f. Weber, as explained by Geertz 1973, p. 5).

14 To be fair, Smith does in other writings offer more substantive descriptions of "religion." In Map is Not Territory: Studies in the History of Religions, for instance, he defines religion as "a distinctive mode of human creativity" that seeks after the "power to manipulate and negotiate one's 'situation' so as to have 'space' in which to meaningfully dwell" (Smith 1993, p. 291). 
Smith, "have not been convincing." Even more problematically, the taxonomic enterprises in question have "been deliberately tampered with for apologetic [read: theological or confessional] reasons." 15 "The most common form of classifying religions, found both in native categories and in scholarly literature," he writes, "is dualistic and can be reduced, regardless of what differentium is employed, to 'theirs' and 'ours'" (Smith 1998, p. 276). Existing classifications in religious studies bespeak "normative implications" or assign "positive or negative valences which render the classification useless" (Smith 1982, p. 6). In other words, personal, theological agendas or "extrinsic apologetics," in Smith's own words (ibid. p. 7), drive religious studies taxonomic systems for various religions in that they employ a set of arbitrary and "illicit" distinctions. In a move that appears satisfying to critical religious studies scholars, Smith identifies the following binaries:

true/false
natural/revealed
with books/without books
natural/ethical
collective/individual
ethnic/universal
cosmic/historical
free/dependent
healthy/sick
affirming/denying
magical/religious
habitual/spontaneous ${ }^{16}$

"I find no value in continuing the effort to make such lists of improperly constructed, impressionistic divisions," Smith claims with regard to phenomenological approaches to the study of religious traditions (ibid. p. 7). "It would be possible, in principle, to construct a proper taxonomy. But this would require abandoning the inappropriate notion of [the so-called] 'essence'" of religion and the application of a polythetic rather than monothetic system of inquiry (ibid. pp. 7-8; 14-15). Smith is optimistic that the comparative and taxonomic methodology, when properly constructed, remains useful.

If Smith rejects the categorical work of the phenomenological school of his day, what does a "proper taxonomy" look like? With the goal of countering the essentializing of religions, Smith calls for scholars of religion to engage in what he calls "polythetic classification" (Smith 1982, p. 8). Under a polythetic classificatory methodology, Smith advances a double set of operations. The first operation includes the identification and selection of "a single taxic indicator" that "appears to function within the tradition as an internal agent of discrimination." Within this first operation, the scholar maps that taxic indicator "through a variety of materials" produced by that religion "in order to gain some appreciation of the range of its application" (ibid. p. 9). To illustrate, Smith uses the example of circumcision within Judaism. Taking Jewish and early Christian textual corpuses as data, he compares and contrasts teaching and instruction with regard to the practice of circumcision in the Hebrew Scriptures, secondary historical literature, and Pauline Epistles. As Smith concludes the first operation, "the wide range of uses and interpretations of circumcision as a taxic indicator in early Judaism suggests that, even with respect to this most fundamental division, we cannot sustain the impossible construct of a normative Judaism. We must conceive of a variety of early Judaisms, clustered in varying configurations" (ibid. p. 14). As for the second operation, Smith takes as data

15 Natalie Carnes (2017, p. 684) summarizes the critical religious studies scholar position, writing that "not all religionists are so ready to forget the way theological and crypto-theological commitments birthed, shaped, and determined the discourse of religious studies and did so in a way that privileged Western Christianity."

16 See Smith (1982, p. 6). 
funerary labels inscribed with such terms as "Hebrew," "Jew," and "Israelite" (ibid. pp. 14-15). From a body of 944 total inscriptions coming from Roman, Galilean, and Egyptian sites, Smith reaches a similar conclusion about these funerary-artifacts-cum-labeling-mechanisms. His taxonomic and cartographic procedure is certainly messier than distilling a religious tradition down to an essence, but it reveals that religious entities such as "Judaism" are actually composed of a "shifting cluster of characteristics which vary over time" (ibid. p. 18). Smith's polythetic program is untidy, but its apparent disorderliness accurately reflects the sociocultural and religious processes of boundary maintenance as groups strive for order. The polythetic method is also adaptable. Scholars trained in a variety of disciplinary methods could engage in the mapping out of myriad different taxic indicators within myriad different socioreligious formations.

By way of review, Smith's methods include robust, extended comparison, on the one hand, and descriptively specific historical studies tracing out the genealogy of a particular concept or practice over time, on the other. Smith's work is highly classificatory and taxonomizing even as it is self-consciously aware of the problematic systems of valuation being applied to the data under scrutiny. Smith insists on taxonomic methods, but resists claims that classificatory work is objective or disinterested. After all, as Smith argues, religion is neither some essential, natural, or obvious category that exists out in the world, in various manifestations, nor a series of iterations just waiting to be identified and encountered by observers. Given that religion is a secondary academic construct, the study of religion is driven by taxonomization and categorization that is defined and put into application by the scholar for a productive heuristic purpose. Comparison, further, "requires the postulation of difference as the grounds of its being interesting (rather than tautological) and [involves] a methodological manipulation of difference, a playing across the 'gap' in the service of some useful end" (Smith 1982, p. 35). Smith here theorizes the gap inherent in any generic act of comparison. Following Smith, taxonomy may represent the most productive means by which to mediate such a gap engendered by comparison and contrast of two (or more) different entities, whether they be religious traditions, rituals, acts of violence, or for the interests of this present article, religious studies subdisciplines.

\section{Classification and Values from Structuralism to Smith}

So far, I've discussed Durkheim and Mauss, Lévi-Strauss, and Smith, paying attention not only to the scholars' respective methodologies but also the more subtle questions of valuation, reflexivity, and description versus prescription. It's important to emphasize that Durkheim and Mauss display their normative commitments in their opposition to understandings of primitive cultures as non- or anti-scientific. ${ }^{17}$ Their controversial position that in primitive classification systems themselves lie the origins of modern science is inherently a value laden stance that subtly gestures toward the awareness of their subjects. But the arguments generally work in one direction as enlightened scholars reveal the hidden mechanisms of so-called "uncivilized" sociocultural formations. I'd like to extend their theories, in a reflexive vein, to the meta-analytical study of the study of religion. ${ }^{18}$ The "classificatory function," to press Durkheim and Mauss's theory further, encompasses even academic "tribes," so to say, engaged in their own scholastic rituals and organized around the totems of the academy. Lévi-Strauss also emerges from the positivist tradition but tantalizingly turns the tables, at the end of The Savage Mind, to implicate the scholar in the study of the other. All minds classify phenomena and delineate taxa, and scholars inescapably (and paradoxically) so as they carry out the study of other groupings. In making these claims, Lévi-Strauss blurs the descriptive/prescriptive distinction. Smith

17 In describing native classification processes as constituted by "a completely logical process" that ultimately serve as the very origins of "scientific" methods to follow (Durkheim and Mauss [1903] 1963, pp. 32, 81), Durkheim and Mauss might plausibly be read as subtly countering popular discursive depictions of primitivism and backwardness in cultural others.

18 I can't take credit for this turn of phrase. It comes from a discussion with Nancy Levene in her office back in 2011, whose 2012 work I draw on in the final section of this article. Additionally, Parimal Patil encouraged a reflexive scholarly stance toward the study of religion in his 2012 keynote address at the Religious Studies Department at Indiana University's graduate student conference, "On Religion: Definition, Delimitation, and Application." 
goes the furthest by revealing the arbitrary-yet-productive academic categorical systems produced for the documentation and analysis of religious phenomena. Smith is decisively prescriptive along some registers-e.g., his pronouncement of good scholarship versus bad scholarship-but it is ultimately his claim that religion is itself an analytic construct to be applied to data under study that collapses any easy distinction. A taxonomy, in Smith's rendering, is an evaluative grid that gestures toward something being justifiable as an object of interest. Smith carries forward the reflexive shift put into motion by the structuralists, arguing for the hyper-awareness of scholars in their comparative studies and admitting that taxonomies are nothing if not valuating, evaluative systems. All the while-citing both The Savage Mind and the Enlightenment's all things knowable mantra (c.f. Levene 2012, pp. 1018-23)-he refuses to allow the comparative and taxonomic method to render "the 'primitive' as some other sort of mind, some other sort of human being" (Smith 1982, p. 61).

Evident weaknesses, including a collapse of agency, an obsession with cultural integration, the implication of some sort of universal, social consciousness, and an overplayed socio-cultural determinacy and staticisity, have rendered the classic structuralist paradigm problematic in the academy and necessitated the subsequent work of the post-structuralists. That cultures, societies, traditions, religions, institutions, and kinship systems serve to inculcate a developing person within formative structures and anchor him or her within systems of self-alignment and order-something of a weak or qualified structuralism, perhaps-appears a convincing theoretical model. The meta-analytical turn in religious studies, aided by Smith, and extended by scholars interested in the methodological nuts and bolts of the academic study of religion, retains a dedication to taxonomic methods while doing away with less convincing parts of the paradigm.

In summary, Smith challenges structuralism in beginning the work to disenchant the position of the scholar. One thus moves decisively away from the view that taxonomies are things that human beings make for various reasons to be studied by scholars to the hyper-reflexive stance that while, yes, people do make and employ taxonomies, scholars also use categorizations in their study of first-order stratagems. Smith lays to rest the ideology of scholarly objectivity and challenges researchers to not only operate self-consciously but also to own up to the valuating processes by which they decide what is or is not worthy of study. Our categories, when constructed thoughtfully, are heuristically valuable. But they are inescapably normative statements nonetheless. That taxonomies are inherently evaluative, however, does not dissuade the theorist from engaging in boundary maintenance within the study of religion. As I've argued, Smith depicts theological prescriptions as data for study, not methods for application. Smith therefore provides a useful taxonomic model as well as a strong warning. While our work as religious studies scholars might posit evaluations of various religious phenomena-perhaps even ascribing valuating descriptors such as "just" or "unjust," morally "acceptable" or "unacceptable"-we must be ever cautious as to the effects of our pronouncements. Are scholars making empirically based, high quality textual or ethnographic observations through thick comparative and contrastive methodologies also spanning temporal and geographic distances? Or do such evaluations amount to nothing more than, as Smith puts it, "illicit divisions" determined by "extrinsic apologetics" which unproductively extend or serve as survivals to the binary judgments of predominantly Christian religionists?

\section{The Normative Turn}

Smith's reflexivity and system for polythetic categorization provides a robust methodology for the study of religion. But Smith also speaks directly to a current impasse in contemporary religious studies over the heated issues of normativity, positionality, and stance, discussions variously framed in dualisms ranging from subjectivity vs. objectivity, to evaluation vs. description, to explanation vs. evaluation, or even religious studies vs. theology. In short, a number of scholars hailing primarily from the philosophy of religion have challenged any easy separation between religious studies and theological inquiries. In this section, I describe the recent normative turn and bring Smith into the discussion. I attend closely to the relationship among taxonomy making, the delineation of data, and the revealing 
or concealing of the position of the scholar within these operations. I focus in the following paragraphs on the respective scholars' discussions concerning the place of theology within religious studies.

The underlying contention following the normative turn is that-whether because of explicit religiosity, theoretical allegiance, or methodological training-all scholarship is value laden. In other words, philosophical and ideological assumptions are constantly at play. In Philosophy and the Study of Religions: A Manifesto (Schilbrack 2014), Kevin Schilbrack intends to broaden philosophy's typically normative stance to include religious studies sub-disciplines that may resist the qualification. Schilbrack proposes a tripartite task for religious studies that involves (1) description, (2) explanation, and (3) evaluation, three methods he contends are more integrated than critics will admit (Schilbrack 2014, p. 142). The most contested of the tasks is the third category of evaluation. On this point, Schilbrack writes:

Now, there is a fair amount of dispute among scholars about whether evaluative approaches ought to be included in the academic study of religions. As I mentioned above, there are some "describers" who hold that the academic study of religions should not include critical approaches that contradict the self-understanding of the religious practitioners, and there are some "explainers" who argue that the academic study of religions should not privilege the practitioners' perspective. I have argued that neither of these two exclusionary arguments is persuasive and that each side should concede the value and legitimacy of the other. Whether or not the describe-only camp and the explain-only camp can get along, however, both sides often agree with each other on this point: the academic study of religions should not include evaluative approaches. Their opposition to evaluative approaches is often termed as a rejection of "theology" (ibid. pp. 147-48).

Schilbrack here refers to a dichotomy central to religious studies lore, that is, to the emergence of and presumed distinction between religious studies methodologies and theological ones (c.f. Cady and Brown 2002). He continues:

Theology, they say, by definition makes evaluative judgments that some religious views are true and that others are false. Any evaluation of religions will reflect the perspective of just one religious point of view, and some describers argue that this is good reason to exclude such judgments from the academic study of religions. And evaluative judgments typically do not operate by public criteria, but rather by tradition-specific criteria, and some explainers argue that this is good reason to exclude them. Despite the disagreements between the describers and the explainers, many in both camps therefore agree that the academic study of religions is best practiced without raising the judgmental and controversial questions of whether religious teachings are true, moral, real, or just (Schilbrack 2014, p. 148). ${ }^{19}$

To solve the conundrum, Schilbrack follows his own call to be clear about normative agendas by re-stipulating more appropriate boundaries for the discipline. "I draw the conclusion that the academic study of religion should be distinguished from other ways of studying religion not by excluding evaluative approaches," he writes, "but rather by excluding claims that cannot be challenged." In Schilbrack's revised program of distinction, one need no longer apply simple binaries because "theology" and "religious studies" overlap in complex ways not taken into consideration by such a dichotomy. Rather, he excludes from religious studies boundaries "the unwillingness to offer reasons for one's claims." Schilbrack sees his approach as "more completely critical" than those who wish

19 Further, oppositions to evaluation fall into what Schilbrack labels as empiricist and critical positions, which proceed out of or are related to logical positivism in philosophy. As an empiricist, Donald Wiebe saw overtly confessional and theological stances (as well as more subtle or implied ones) as out of place in the academy. And in the latter position, Russell McCutcheon distinguishes between critics and caretakers, privileging the first category but actually conceding that all scholarly endeavors are underwritten by normative commitments of different types (Schilbrack 2014, pp. 150-53; c.f. Omer 2011). 
simply to exclude theological inquiries. He thus re-appropriates "the critical" descriptor for use in his new paradigm (ibid. p. 155), effectively shifting the conceptual and discursive terrain of the field.

In conversation with Schilbrack's work is Thomas Lewis' Why Philosophy Matters for the Study of Religion—and Vice Versa (Lewis 2015). Like Schilbrack, Lewis focuses on what he views as the over-simplistic distinction between religious studies scholars, on the one hand, and theologians, on the other. The problem for Lewis is that the binary hinges on the issue of normativity. "In much of this debate," he writes, "a crucial background assumption-sometimes stated but often not-is that whereas theologians make normative claims, religious studies scholars should refrain from doing so." "Rather, scholars in religious studies should distinguish themselves from theologians precisely by striving for some type of distance, neutrality, or objectivity in relation to their subject matter, where this is understood to entail analysis regarding what is rather than claims about what ought to be" (Lewis 2015, p. 45). Like Schilbrack's trifold methodology, Lewis similarly rejects a descriptive/prescriptive distinction. "Framing the debate in terms of theology and religious studies," he avers, "is ultimately neither intellectually defensible nor heuristically productive" since normative claims and values "are inevitable in the study of religion" (ibid. p. 46).

Lewis spends a good deal of space helpfully clarifying what normativity is. Normativity obliges, guides, or disposes the actor (c.f. Korsgaard 1996). Normativity concerns not only morality, but also a wider sphere of operational judgments. In a phrase resonating with Smithian reflexivity, Lewis implies that normativity is part of the human condition and that scholars themselves "inevitably make normative judgments regarding the materials and people they are studying" (Lewis 2015, pp. 48, $49 \mathrm{ff}$.). Even propositions by Timothy Fitzgerald, whose goal is, according to Lewis, "to transform religious studies in part by ridding it of pervasive theological presuppositions-is itself thoroughly normative and concerns more than the norms of inquiry itself" (ibid. p. 51). Similar to Schilbrack, Lewis desires to broaden the boundaries of the field in an inclusive, widening manner (ibid. p. 60). But echoing Schilbrack (and Smith), Lewis also recasts his own prescriptive taxonomy of good and bad scholarship. Schilbrack excludes scholarship, "theological" or not, that refuses to offer a rationale for claims purported. Lewis likewise dismisses those who make appeals to the authority of personal experience, faith, or internal feelings, claims that cannot be "subject to constructive debate by a larger [academic] community" (ibid. p. 61). Nevertheless, Lewis does not claim to restrict religious studies to certain non-theological forms but rather opens it up to "the plurality of types of investigations" (ibid. p. 61) the interdisciplinary field may offer. ${ }^{20}$ Schilbrack and Lewis propose an inclusive vision for and cultivate "space for diverse approaches within religious studies" (ibid. p. 61).

What does all this have to do with the genealogy of taxonomic thought that Smith inherited? The normativists argue at least partially in resistance to Smith's suggestion that religious studies scholars dismantle "old theological and imperialistic impulses" (Smith 1982, p. 18). As Schilbrack notes, older theological and colonialist impulses were certainly misguided, as are those theological forms that refuse to provide public support for their claims. ${ }^{21}$ Smith concedes the importance of theological traditions but primarily as objects of study for historians of religions and not as scholarly colleagues or an academic sub-field, per se (ibid. p. 43). It may even initially appear that Smith fails to qualify for Schilbrack's tri-fold program in that he endorses description and explanation, methods one and two, but resists the third by denying any explicit program of evaluation or judgment. But this is not exactly the case. In "The Devil in Mr. Jones," as Levene clarifies, Smith riffs on Montaigne's "Of Cannibals" essay to conclude that "we cannot judge another culture by reference to ourselves; we

20 Lewis's position is certainly complex. For while he advocates for the inclusion of theology within religious studies, he also rejects the strategies of other scholars, namely Rudolf Otto, whom he views as problematically removing himself from dialogue with certain types of audiences or publics. Otto, according to Lewis, closes off discussion rather than allows for self-scrutiny (Lewis 2015, pp. 60-61). For a claim that Why Philosophy Matters may unduly referee between "what counts as religious studies" and what does not, see Carnes (2017: esp. pp. 685-86). On Carnes's view, Lewis acts similarly to the critical religious studies scholars in his engagement in disciplinary boundary maintenance.

21 Personal correspondence with the author (November 10, 2016). 
may judge (both another and ourselves), if our criteria are universal 'rules of reason'" ibid. p. 105; c.f. Levene 2012, p. 1018-23). Smith's statement on universal rules, then, overlaps with the territory of evaluation proposed by Schilbrack and supported by Lewis. Further, as Levene riffs on Smith, "We can judge because we can come to understand. To understand is to see them-to presume from the outset that they are-like us" (Levene 2012, p. 1020). Smith allows for evaluation and normativity at least along certain junctures, that is, in light of the shared ingenuity of the human mind proposed by the structuralists.

Further, one might recall that as performances of power-as intentionally hierarchical entities created through the scholarly gaze-taxonomies both construct and analyze data. Smith thoroughly reconfigures the methods by which religious studies scholars construct data, but where exactly he falls in debates about objectivity and positionality is a matter of interpretation. Smith's writing is polysemous. His texts, as John Parrish claims, engender a "plurivocity" (Parrish 2009, p. 441) of interpretation. Some normativists clearly see scholars following in Smith's wake as refusing to allow theologians into the religious studies fold. But in doing so, they might miss an opportunity to re-define for the academy both (a) what counts as data for the study of religion and (b) what counts as "critical" religious studies scholarship. I would go as far as to suggest that the normativists are actually in need of Smith in order to advance the contours of the future of religious studies as they imagine it. ${ }^{22}$ Schilbrack's interaction with Smith supports this claim. Smith, for instance, fashions theological work as data but has a very narrow type of theology in mind when he does so. Smith's dismissal does not take into account scholars trained in theological studies who are also well-versed in critical theory, feminism, and post-structuralist thought. In fact, his stipulation of theologians as data refers only, in his own words, to those concerned "with canon and exegesis" (Smith 1982, p. 43). Hypothetically speaking, it may even be the case that particular types of theological scholarship can take up and employ Smith's highly comparative methods and strategies of polythetic classification toward their own and other theological traditions. This polysemy is what makes Smith's work such fertile ground for encounter between religious studies factions. The determining of an entity as data is at once a taxonomic maneuver and internecine boundary maintenance strategy.

Consider the various religious studies stances on theology's inclusion or exclusion within religious studies. With regard to theology, normativity, and data for study, at least two positions, roughly speaking, are in operation. For some time, critical religious studies scholars, inspired by Smith, have suggested that theological inquiry provides religious studies with data for analysis (McCutcheon 2002; Smith 1982; c.f. Strenski 2002). McCutcheon, for instance, conceives of any grand explanatory, totalizing, or normative stance taking—including theology—as data (McCutcheon 2014, pp. 56-57; McCutcheon 2002, pp. 14, 18-19). Resisting this view, the normativists re-stipulate what counts as data, countering with a second position: Any claims withdrawn from the arena of "constructive debate by a larger community," that is, any subject positions or normative values not critically challenged, do not belong to the armamentarium of valid religious studies approaches. One camp views theology as data. The other claims some forms of theological inquiry as credible and counters that unexamined, normative biases—whether scholarly, philosophical, or religious—are not admissible in the academy. On my view, the normativists would advance their cause by further interacting with and appealing to Smith's intermeshed theories of religion, taxonomy, polythetic categorization, and reflexivity. ${ }^{23}$

22 For a similar situation, see the debate between Atalia Omer and Russell McCutcheon (Omer 2011; McCutcheon 2014, esp. 195-213), a debate which continued between Omer (2013) and K. Merinda Simmons (2013).

23 Smith's writings have been influential across the religious studies camps. Smith is a strong influence on McCutcheon's own theorization on the study of religion. For a few examples of Smith's frequent appearance in the latter's work, see McCutcheon (2014), a collection of essays written by the author between 1990 and 2013. Smith shows up, in multiple chapters and in varying degrees of detail, some twenty-four separate instances. Smith's usefulness is illustrated by the fact that some normativists are also finding him useful for thinking methodology in religious studies. Schilbrack, for instance, refers to Smith on the subject of defining religion in his Philosophy and the Study of Religions (Schilbrack 2014, pp. 90-91, 105, 106, etc.; c.f. Martin 2017, p. 9 on this point). Lewis also engages with Smith on the subject of religion's contestedness in his 
Religions, in his understanding, are those systems that engage in complex strategies of concealment in order to hide the contestedness and fraughtness of their taxonomic formations. In other words, through a Smithian frame the normativists can critically alter the data purview for religious studies as a broader collective. Such a reorientation of what counts as data or not for method and theory scholars is no small feat.

Herein lies a yet unrealized but dramatically possible reversal. Are not scholars appealing to objectivity and neutrality thus concealing — be it actively, passively, or involuntarily - their own normative agendas? Acts of value concealment, we learn from Smith, are data for study. No matter their origins, strategies of concealment constitute fodder for critical analysis by scholars of religion following Smith. For normativists, old school positivists and anti-theology discourses count as and, in quasi-religious strategies of suppression, constitute data. Perhaps the tools for the deconstruction of "neutral and scientific" approaches to the study of religion (Smith 1982, p. 111; Levene 2012, p. 1020) lie in the very sources that entertain, however fleetingly, the ephemera of objectivity.

\section{Conclusions}

Let me conclude by following the challenge to make explicit one's intellectual commitments. Although the normativists' proposals make important advances in religious studies by disenchanting the idea of scholarly objectivity, expanding conceptions of the critical, and possibly even altering the religious studies purview for what counts as data, on my view several major issues remain. First, one worry is that admitting theological perspectives into the discipline may serve to reinforce and normalize liberal-theological hegemony rather than challenge it with more robust forms of pluralism. The justifiable concern is that legitimating theological inquiry as a viable religious studies methodology still distinguishes "good from bad theology" (Carnes 2017, p. 686), therefore reproducing the very binaries Smith identified and resisted. The normativists simply create "an additional level of refereeing about what counts as religious studies" (Carnes 2017, p. 685). Liberal (i.e., "critical" or "academic") theology may now have a place at the table, but such patterns of inclusivity in practice will doubtfully leave room for non-liberal theological expressions (Curtis 2015; see Lewis 2015, pp. 52-56 for a counter perspective). In other words, Lewis' claim that "we should not necessarily exclude people from the field just because we do not agree with the arguments they offer in favor of their positions" (Lewis 2015, p. 55) sounds idealist at best. Second, one may counter that the normativists' claim that critical religious studies scholars resist taking account of normativity or positionality is in some situations little more than caricature. Several influential scholars in the critical camp, for instance, call for making clear subject positions and biases (Martin 2016; c.f. McCutcheon 2015, p. 3). McCutcheon's comments that "no academic work is pure of evaluative commitments" and that all scholarship is "perspectival, politically implicated, and value-laden" (as quoted in Schilbrack 2014, p. 152) suggest that critical religious studies scholars' positions on the attainability of objectivity are quite complex. Third, might the normative turn throw the proverbial baby out with the bathwater by lumping together all appeals to or operations of objectivity as of the same value and leverage? In other words, I agree with Martin (2016; c.f. 2017) that what is needed is an even more exhaustive and critical taxonomy of appeals to both objectivity and normativity than has been provided. Perhaps even here Smith will be of service.

Acknowledgments: Many thanks to Bharat Ranganathan, Gary Slater, Anil Mundra, and Kevin Schilbrack for extended feedback on this article at various stages of its production. I presented an early version of the paper in Atlanta at the 2015 American Academy of Religion meeting and am grateful for the constructive feedback received from the Philosophy of Religion Section audience. Special thanks goes to Bharat Ranganathan for organizing the panel and guest editing this special issue, to the editorial staff at Religions for hosting our articles, and to three blind reviewers who took the time to help improve my work.

book (e.g., Lewis 2015, pp. 127, 131, 143n17). But more interaction with Smith could be brought to bear on the discussion about normativity and the boundaries of religious studies. 
Conflicts of Interest: The author declares no conflict of interest.

\section{References}

Barnard, Alan. 2000. History and Theory in Anthropology. New York: Cambridge University Press.

Briggs, Rachel, and Janelle Meyer. 2009. "Structuralism." Anthropological Theories (UA Dept. of Anthropology). Available online: http:/ / anthropology.ua.edu/cultures/cultures.php?culture=Structuralism (accessed on 24 July 2015).

Linell E. Cady, and Delwin Brown, eds. 2002. Religious Studies, Theology, and the University: Conflicting Maps, Changing Terrain. Albany: State University of New York Press.

Carnes, Natalie. 2017. Review of Why Philosophy Matters for the Study of Religion-And Vice Versa, by Thomas A. Lewis. Modern Theology 4: 684-86. [CrossRef]

Cohen, Henri, and Claire Lefebvre. 2005. Handbook of Categorization in Cognitive Science. Oxford: Elsevier Ltd.

Cosman, Carol. 2001. Introduction. In The Elementary Forms of Religious Life. Translated by Carol Cosman. Edited by Emile Durkheim. New York: Oxford University Press, pp. vii-xxxv. First published in 1912.

Curtis, Finbarr. 2015. It's Not the Size of the Tent; It's How It's Constructed. Leviathan and You: A Blog about Big Things, October 16. Available online: http:/ /leviathanandyou.blogspot.com/2015/10/its-not-size-of-tentits-how-its.html (accessed 28 September 2016).

Douglas, Mary. 1966. Purity and Danger: An Analysis of the Concepts of Pollution and Taboo. Boston: Routledge \& Kegan Paul.

Durkheim, Emile. 2001. The Elementary Forms of Religious Life. Translated by Carol Cosman. New York: Oxford University Press. First published 1912.

Durkheim, Emile, and Marcel Mauss. 1963. Primitive Classification. Translated by Rodney Needham. Chicago: The University of Chicago Press. First published 1903.

Foucault, Michel. 1972. The Archaeology of Knowledge and the Discourse on Language. Translated by A. M. Sheridan Smith. New York: Pantheon Books.

Foucault, Michel. 1994. The Order of Things: An Archaeology of the Human Sciences. New York: Vintage Books.

Geertz, Clifford. 1973. The Interpretation of Cultures. New York: Basic Books, Inc.

Geertz, Clifford. 1998. Works and Lives: The Anthropologist as Author. Stanford: Stanford University Press.

Hall, Edward T. 1989. Beyond Culture. New York: Anchor Books (Doubleday).

Korsgaard, Christine. 1996. The Sources of Normativity. Edited by Onora O'Neill. Cambridge: Cambridge University Press.

Lévi-Strauss, Claude. 1961. Tristes Tropiques. Translated by John Russell. New York: Criterion Books.

Lévi-Strauss, Claude. 1963. Totemism. Translated by Rodney Needham. Boston: Beacon Press.

Lévi-Strauss, Claude. 1973. The Savage Mind. Chicago: The University of Chicago Press.

Levene, Nancy. 2012. Courses and Canons in the Study of Religion (With Continual Reference to Jonathan Z. Smith). Journal of the American Academy of Religion 80: 998-1024. [CrossRef]

Lewis, Thomas A. 2015. Why Philosophy Matters for the Study of Religion-And Vice Versa. New York: Oxford University Press.

Lincoln, Bruce. 1999. Theorizing Myth: Narrative, Ideology, and Scholarship. Chicago: University of Chicago Press.

Marshall, Gordon. 1998. Structuralism. In A Dictionary of Sociology. New York: Oxford University Press, pp. 646-48.

Martin, Craig. 2016. Disambiguating Normativity. Available online: https:/ /craigmartinreligion.wordpress.com/ 2016/07/22/disambiguating-normativity/ (accessed on 27 September 2016).

Martin, Craig. 2017. "Yes, ... but ... ": The Neo-Perennialists. Method and Theory in the Study of Religion 29: 1-14. [CrossRef]

Mauss, Marcel. 2005. The Nature of Sociology: Two Essays. Translated by William Jeffrey. New York: Durkheim Press/Berghahn Books. First published 1901.

McCutcheon, Russell T. 2002. The Study of Religion as an Anthropology of Credibility. In Religious Studies, Theology, and the University: Conflicting Maps, Changing Terrain. Edited by Linell E. Cady and Delwin Brown. Albany: State University of New York Press, pp. 13-30.

McCutcheon, Russell T. 2014. Entanglements: Marking Place in the Field of Religion. Bristol: Equinox Publishing Ltd. Russell T. McCutcheon, ed. 2015. Fabricating Origins. Bristol: Equinox Publishing Ltd.

Nietzsche, Friedrich. 2003. The Genealogy of Morals. Mineola: Dover Publications, Inc. First published 1913. 
Omer, Atalia. 2011. Can a Critic Be a Caretaker too? Religion, Conflict, and Conflict Transformation. Journal of the American Academy of Religion 79: 459-96. [CrossRef]

Omer, Atalia. 2013. In the Critic vs. Caretaker Dichotomy A Magic Dwells: Parroting McCutcheon, Policing "Religion" (A Rejoinder to Merinda Simmons). Method and Theory in the Study of Religion 25: 382-402. [CrossRef] Parrish, John W. 2009. You Show Your Smith and I'll Show Mine: Selection, Exegesis, and the Politics of Citation. Method and Theory in the Study of Religion 21: 437-59.

Porth, Eric, Kimberley Neutzling, and Jessica Edwards. 2009. "Functionalism." Anthropological Theories (via the University of Alabama Department of Anthropology). Available online: http://anthropology.ua.edu/ cultures / cultures.php?culture=Functionalism (accessed on 4 February 2016).

Schilbrack, Kevin. 2014. Philosophy and the Study of Religions: A Manifesto. Malden: Wiley Blackwell.

Simmons, K. Merinda. 2013. Protective Parroting: A Rejoinder to Atalia Omer. Method and Theory in the Study of Religion 25: 403-7. [CrossRef]

Smith, Jonathan Z. 1982. Imagining Religion: From Babylon to Jonestown. Chicago: The University of Chicago Press. Smith, Jonathan Z. 1993. Map Is Not Territory: Studies in the History of Religions. Chicago: The University of Chicago Press.

Smith, Jonathan Z. 1998. Religion, Religions, Religious. In Critical Terms for Religious Studies. Edited by Mark C. Taylor. Chicago: The University of Chicago Press, pp. 269-84.

Smith, Jonathan Z. 2004. Relating Religion: Essays in the Study of Religion. Chicago: The University of Chicago Press. Strenski, Ivan. 2002. "Why 'Theology' Won't Work”. In Religious Studies, Theology, and the University: Conflicting Maps, Changing Terrain. Edited by Linell E. Cady and Delwin Brown. Albany: State University of New York Press, pp. 31-44.

(C) 2017 by the author. Licensee MDPI, Basel, Switzerland. This article is an open access article distributed under the terms and conditions of the Creative Commons Attribution (CC BY) license (http:/ / creativecommons.org/licenses/by/4.0/). 